\section{アラミド繊維補強を用いた木造 HP シェルと鉄骨張弦梁による ハイブリッド構造の設計（その 1)}

一山寺郵便局の構造デザインとその展開一

\title{
DESIGN OF HYBRID STRUCTURE CONSISTING OF STEEL BEAM STRING STRUCTURE AND WOODEN HP-SHELL REINFORCED BY ARAMID FIBER (PART 1)
}

-Development of the structural design of the Yamadera Post Office-

\begin{tabular}{|c|c|}
\hline$-* 1$ & 倠人 -*2 \\
\hline カトフ 一*3 & 小田島正仁 一 $* 4$ \\
\hline $\begin{array}{l}\text { 幾島亜希子— } * 5 \\
\text { 板垣直行 }-* 7\end{array}$ & $\begin{array}{l}\text { 鈴木良博 —*6 } \\
\text { 伊藤邦明 一 } * 8\end{array}$ \\
\hline
\end{tabular}

Toshihiro AlHARA -*1
Marin KATOV $-* 3$
Akiko IKUSHIMA - $* 5$
Naoyuki ITAGAKI $* 7$

The research and development of hybrid structures cannot be referred as one with sufficiently actual results. In this report we suggested the wooden HP shells made by lumbers of two layers by which the direction lies at right angles with the lugscrew bolt. Here, an aramid fiber sheet is introduced into four wooden HP shells so that the intensity and rigidity of the shells are strengthened. This hybrid structure further combined with steel string beam structure is applied to Yamadera Post Office in Yamagata Prefecture.
1.はじめに

近年建築構造の分野において、ハイブリッド槽造の開発・研究が 進んできている。ここで苔うハイブリッド構造とは、単に一つの部 材が異種の材料の組み合わせで出来ているばかりではなく、架構の それぞれが、異なる構法の組み合わせによって出来ている事が必要 である。そしてその事により単ーシステムの樓造にはない性能の発 展や空間の魅力を獾得しているものとして捉えたい。このような考 えうは研究・開発の分野においてもまだ始まったばかりであり、実 例もそれ程多くないと思われる。設㯢の実務の分野においても、今 後様々な発展形が望まれている状洗と考えられる。

ここでは、直交した 2 層の木板の交差部をラグスクリューボルト によって固定し、構成した 4 枚の木造HPシェルにアラミド辕維シー 卜を薄入してシェルの強度と剛性を補い、さらに铁骨張弦梁を組み 合わせて架構全体の安定性を確保して、新しいシステムによるシン プルで軽快な粠造空閒を演屾し、山形県の山寺郵便局の殷計（設計： 南一盛十伊藤邦明）において応用した構造設計例を報告するものて ある。
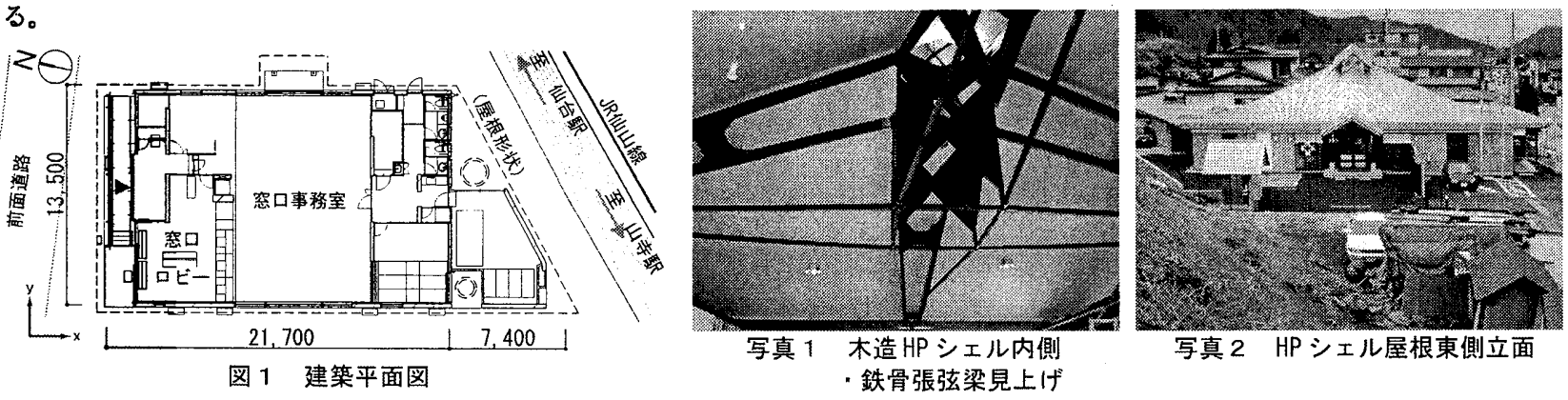

写真 2 HP シェル屋根東側立面
2. 山寺郵便局について

山寺立石寺は芭蕉の句でも知られる古刹である。下から睍上げる 山容や中腹加胃下ろす景锶は、一時は年間 100 万人を超える参拝客 を悲きつけた﨡力を持っている。建物敂地はこの立石寺の南のふも と、J R 山寺駅の近くにあり、景観上の配磨を意識する場所である と共に、この地は㴪雪地帯であり設計用皘雷深度は $100 \mathrm{~cm}$ である。

征便局の主要な空間はロビーと一体化した事務空空間であり、柱 のない広々とした空間に柔らかい反射光がトップライトからシェル の曲面をな寸天井に沿って落ち、職場の快適性を支えるであろうこ とも意図した。

この郵便局の設計に相怘しいと考えられた構造と構法を追求した 結果、アラミド瀻維シートによって補强されたフィンランド産製材 による木造HPシェルと鉄骨張弦梁架棒からなるハイブリット權造に よる㹩快な屋根が考えられた。この形は屋根の中央部に降り積もっ た雪を屋根周辺部に滞雪させ、屋根荷重の中央集中を避けてその軽

\footnotetext{
*1 東北大学大学院工学研究科都市 - 建築学専攻 博士後期課程·工修 （干980-8579 仙台市青葉区荒巻字青葉06） 釈 S.D.G.代表

*2 東北大学大学院工学研究科都市 - 建築学専攻 博士前期課程

*3 東北大学大学院工学研究科都市・建築学專攻 助手. 工博

*4 侏伊藤都市建築研究所

*5 橉 S.D.G.

*6 怢 C.A.E.

$* 7$ 秋田県立大学システム科学技術学部 講師・工博

*8 東北大学大学院工学研究科都市 · 建築学専攻 教授 $\cdot$ 工博
} 
減を意図すると其に、寺院建筮の特徽である反った大崖根をも意躘 しており、タ日を浴びた姿根のシルエットは山寺の秉囲気によく溶 け込んでいると感じられる。

\section{3．木造 HP シェルと鉄骨張弦梁によるハイブリッド構造}

\section{3-1 ハイブリッド構造の成立}

建物屋根を構成するのは 4 枚の木造HPシェルを組み合わせたもの であるがその平面内に直接屋根の鉛直街重を受ける柱等の支持材は 無い。当初の計画ではピラミッド状のフレームを $x, y$ 雨方向の中央に 設ける事などが考えられたが、構造検郡を進めた結果、積掣大荷重 に対してはテンションバーを用いて推力（スラスト）に对応し、满 造全体に强度と剛性を与える鉄骨張弦梁構造との併用がスマートな 方法と考えられた（図2）。

しかも積雪荷重に対してのみではなく、風荷重や地㖘力に対して も安定した性能（强度と変形）を保ちながら外周に配置された釷筋 コンクリート造の下部構造へカを层達する為には、単なるテンショ ンバーのみならず中央部に鉛直材を設けて压縮側の上弦材と結び、 トラスの要素を持たせて屋根全体の剛性を確保するのが良いとの俟 郡結果を得て、この跺直材を丸鎆棒で細く作ることによって軽快さ を表見しながらも有效な架構とすることが出来た。

テンションバーは 2 枚一組のフラットバーとし、照明機器の取付 用レールと一体となって意匠的に見せるものとなった。

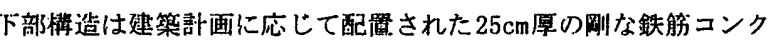
リート造耐力壁によって構成されており、剛な麻架構と一体になっ て地震・程雷等の荷重を支持している。

このように、上部より「柔（木造シェル）」と「強（鉄骨張弦トラ ス架構)」と「㓯（鉄筋コンクリート壁式構造）」の組み合わせによ るハイブリッド構造が成立するに至ったのである。

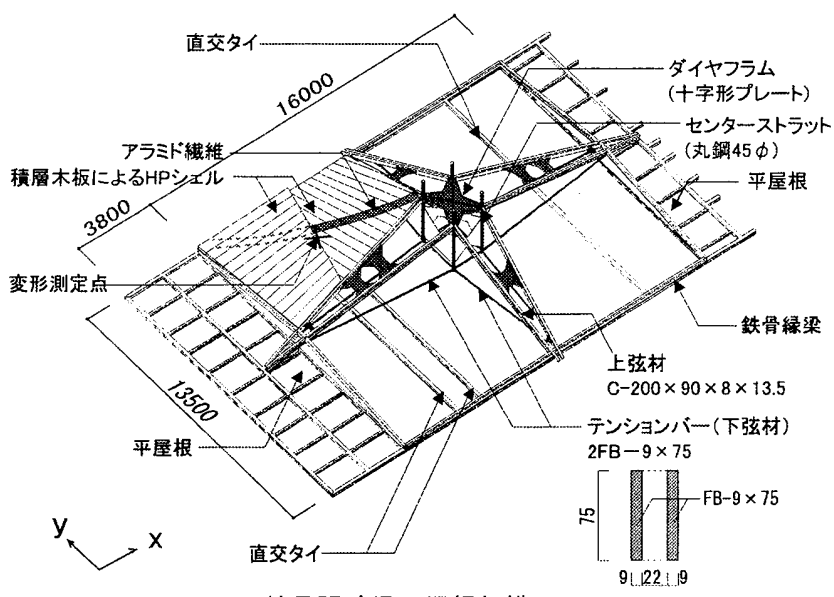

図 2 鉄骨張弦梁・屋根架構システム

3-2 システムの構成

3-2-1 木造 HPシェル

当初の意匠設計側からの提案は、木製のフラットバー（25 mm 掌× $140 \mathrm{~mm}$ 幅）を橎き亚べたものを、材軸が直父するように2署に重ねて シェルを粠成することが出来ないか、というものであった。4枚の シェル構造の 1 玟のサイズが $6.5 \mathrm{~m} \times 8.0 \mathrm{~m}$ 程度であり、䅡雪が $100 \mathrm{~cm}$ $\times 30 \mathrm{~N} / \mathrm{m}^{2} / \mathrm{cm}=3,000 \mathrm{~N} / \mathrm{m}^{2}$ という備しい基本荷重条件であったが、
榆㨍を重ねたところ不明な点は残るが成立の見通しが立ち、㖕画を 進めることとなった。

板と板の幅方向の取り合い部は、コスト低減と施工性向.上の観点 から㕍い実（やといざね）とし、板の剛性については上下の層の接 合を強度・甽性に信頼性のあるラグスクリューによる接合と才る事 で確保することとした。そのため設計上は $5 \mathrm{~cm} /$ 量の木板としての解析 と、更に一体化が失われてきた場合のために 1 枚の $2.5 \mathrm{~cm}$ 厚の場合の 解析も行った。そしてHPシェルの面内・面外応力に対して、1 枚で も啋容值以内にほとんど収まっていることを確認した。

HP シェルの水平唰性注境界条件の有利さにより確保される。この 4 枚のHPシェルは各々 4 辺が $10 \mathrm{~cm}$ 角材にラグスクリューボルトで固 定される事によりビン支持されている。このうち3 辺はさらに材が 延長され隣の HPシェル又は同粠法の平屋根と一体となり、水平変形 が拘束されている。残る外周 1 辺は鉄骨の緑梁（裙梁）上の角材で 支持されて屋根の縁を形成しているから、拘束されている隅角部の 間でのはらみ出しによる水平変形のみの許容とする事ができる。し かしこのはらみ出しは縁梁を中間でつなぐ直交タイで殆ど抑えられ るため、周辺自由なHPシェルに比べ同厚でも剛性・强度レベルはか なり高いものとして設計することが出来ている（図2、図3）。

屋根全体のHPシェルのトップからボトムにかけての対角線方向に ついては、主応力である引張力に加えて面内ねじれせん断力も作用 するためこれが本シェルにおける最大応カソーンであると判断し、 アラミド䄉維シートを接着剂を使用して上下層の間に挟んで一体化 する補強を行ったが、これについては施工の項にて後述する。

材種に関しては設計の早い段階から稌討が行われ、コスト面の有 利さと乾煤収縮が少ない点からフィンランド産ホワイトウッド（ス プルースの一種) とした。もうひとつは、シェル面がそのまま室内 仕上げ面として見えるために肌合いの良いものを選んだ。

部材サイズ (板幅) に関しては規格品としてロットが存在する部 材サイズを使用するという事から $140 \mathrm{~mm}$ で決定に至っている。
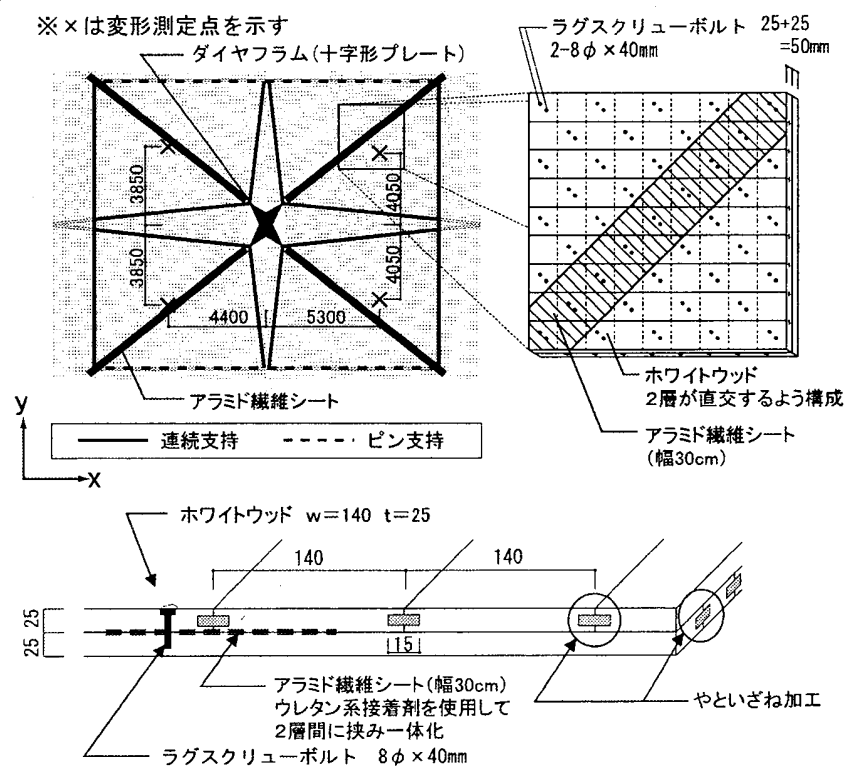

図 3 木造 HP シェル構成図・やといざね詳細図 


\section{$3-2-2$ 铁骨張弦梁}

鉄骨張弦梁架橉はx,y各方向のスパン上中央に井析状に配置した4つ のトラスによって構成されている。このトラスは压縮側となる上弦

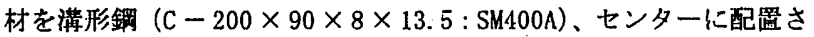

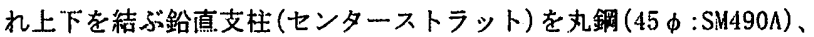
そして引張側となる下弦材を 2 本 1 組のフラットバー $(2 \mathrm{FB}-9 \times 75$ :

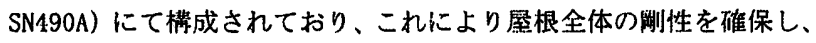
かつHPシェルのスラストに抵抗するものとしている。上弦材は $\mathrm{x}, \mathrm{y}$ 各方向の部材が中央の答差部において、斜めのダイヤフラム（十字 形プレート）によって一体化されて水平䒽性を保っている（図2）。 $3-2-3$ 各部材料

(1)ラ゙スクリューボルト

本HPシェルは $\mathrm{x}, \mathrm{y}$ 各方向に直交するように配置した板材が 2 層に 重なったものとして構成されているが、この上下層を一体化する為 に强度・剛性に信頼性のあるラグスクリューボルト $(8 \phi-40 \mathrm{~mm})$ を 使用して強固な一体化を目指すこととした。面内ねじれせん断力に 対してはこのラダスクリューボルトのせん断耐カが支配的な抵抗要 慗であると考えられる。

\section{(2アラミド織維シートの操用と接着剤}

先述した通り木HPシェルにおいては、トッブからボトムにかけて の対角線力向に主応力である引張応力が作用し、さらに面内ねじれ せん断応力も存在することから、この最大応カソーンにアラミド織 維シートを配置することとした。単純にHPシェルの菱形変形の抑制・ 強度の確保という観点で板の存在応力を解析して検討し、シート幅 は $300 \mathrm{~mm}$ として（JISによる保証耐力の試験值 $157 \mathrm{kN} /$ 枚）接着郕を使 用して上下の層の間に接着して挟み込むことで十分な効果が期待で きると判断した（図 3)。

また接着凨については、実建物において使用実績のあるウレタン 樹脂系接着剂を採用している。

\section{4. 木造 HP シェルの応カと変形}

本建物に使用したHP シェルの応力解析は有煺要絭法解析により 行った。木造HPシェルの 1 枚を $15 \times 15$ の矩形ユニットに分割し、鉄 骨·矤弦梁架橉は線材に置換して車者を一体化して解析を行った。ま た、解析全体の整合性の確認の為に鉄骨張弦梁架構のみを取り出し て、3 次元立体解析を別途行った（表 1、図 4)。

結果として張弦梁架構中央部のたわみは両者において $0.75 \mathrm{~cm} 〜$ $0.86 \mathrm{~cm}$ となり、比較的合致したものとなった。ただし木材に関して は後述の材料実験から得られた弹性俰数を解析に用いたが、せん断 弾性俰数については使用解析ソフトの解析条件制限の関倸. $\mathrm{E} \mathrm{G}=$ $0.25 \mathrm{E}$ としているため、別途実施したせん断実験より得られた值よ りかなり大きい数值となっているので、シェルの応力解析結果の取 り扱いに関しては参考俌として考虑するという事になる。

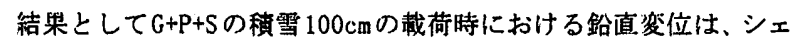
ル中央部において約 $10 \mathrm{~mm}$ 程度であるから、シェル1枚の短辺スパン 5. $5 \mathrm{~m}$ に対して約 $1 / 550$ に収まっておう、無理がなくかつ過剩でもな い䝵切な状況であると考えられる。
表 $1 H P$ シェル解析条件一覧

\begin{tabular}{|c|c|c|c|c|}
\hline C. & $E\left(\mathrm{kN} / \mathrm{mm}^{2}\right)$ & $\mathrm{G}\left(\mathrm{kN} / \mathrm{mm}^{2}\right)$ & 解析モデル & 荷重条件 \\
\hline 1 & \multirow{3}{*}{1.612} & \multirow{3}{*}{0.108} & \multirow{3}{*}{ 原さ50mm換算 } & $G+P$ \\
\hline 2 & & & & $G+P+S($ full $)$ \\
\hline 3 & & & & $G+P+S(20-50)$ \\
\hline 4 & \multirow{3}{*}{12.861} & \multirow{3}{*}{0.108} & \multirow{3}{*}{ 厚さ25mm換算 } & $G+P$ \\
\hline 5 & & & & $G+P+S(f u l l)$ \\
\hline 6 & & & & $G+P+S(20-50)$ \\
\hline
\end{tabular}

※弾性係数·せん断弾性係数は实験結果報告に基づ平均值を採用。 ※弾性係数について、1.612は板厚50mmとして換算したもの、 12.861は板厚 $25 \mathrm{~mm}$ として換算したもの。単位はいずれも $\mathrm{kN} / \mathrm{mm}^{2}$ ※せん断弾性係数について、0.108はアラミド織維補強ありの時の算定值。 単位はkN/mm²。

※荷重条件中、S(雪荷重)について、(full) とは $100 \mathrm{~cm}\left(3000 \mathrm{~N} / \mathrm{m}^{2}\right)$ 考虑時、 (20-50)とは実情に近い $20 \mathrm{~cm}$ (頂部) 50cm(下部)の積雪考虑時のこと。

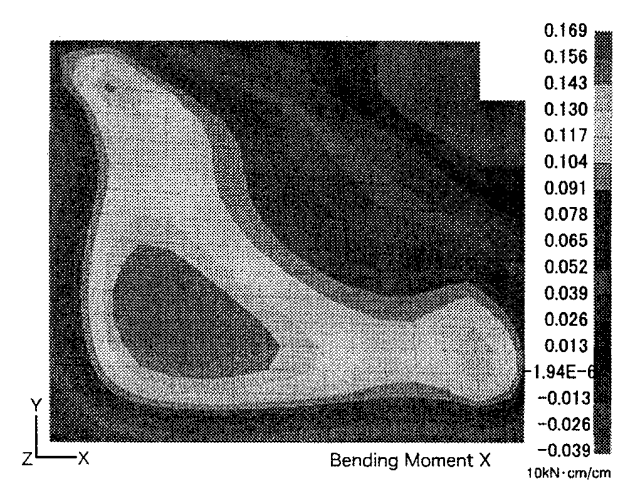

図 4 FEM 解析結果 (CASE2 一曲げ応力)

\section{5. 施工}

本敬地の地盤仙表層からすぐにN值50以上の良好な砂磻層が露出 しているので、基礎は地中梁を含む哪な礴板となる鉄筋コンクリー

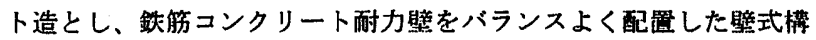
造として上部の座根架搆を支える形式としている。本報告では鉄骨 工事と屋根（HPシェル）工事について報告を行う。

\section{5-1 鉄骨工事}

瘚しい建設コストを考えると、特殊な張弦梁棈造といえども合理 的に製作できる必要があったので、部材は市肘のH鋼や澁形鋼及び フラットバーなどを用い、取り合い詳細もボルト接合を中心として 出来るだけ简略化を図った。しかしながら張弦の引張纫力が集中す る中心部では、センターストラットは接合部において機械粠造用の 丸鋼を削って四角形として、引張力を伝達するフラットバー突合せ 溶接としており、施工者には本简所の溶接には稩心の注意を払って もらう事とし、その結果超音波探甥試伢において合格火陥もほとん ど無い良好な施工とすることが出来た。

またボルト接合部が多くあるため、出来上がりの寸法俱差の目標 を $1 \mathrm{~mm}$ 程度として工場内で仮組みを行って調整し、製作精度が確保 できることを予め確認した。そこで現場では特にキャンバー（起り） を設けずに製作を行ったが、支保工除去後の鉛直变位は約 $15 \mathrm{~mm}$ あった。

\section{5-2 木造工事（犀根工事）}

HIP シェル夙辽部において、 R C 造耐力壁の上部に鉄骨の縁梁（裙 梁）を配罱して瓷根のHPシェルを受けることとしているが、この鉄 骨緗染と木造のシェル本体を直接接合・困定することは土法上無理 がある。そこでこの雨者の接合を容易にし精度を確保するために、 閐に $100 \mathrm{~mm}$ 角の木材 (米アツ) を設置した。これにより鉄骨梁と角材 をボルトジョイントとし、角材と木造HPシェルを釘打ち（ラグスク 


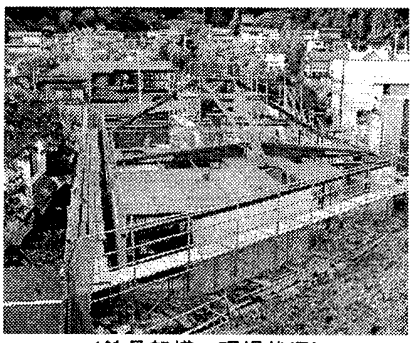

(鉄骨架構・現場状況)

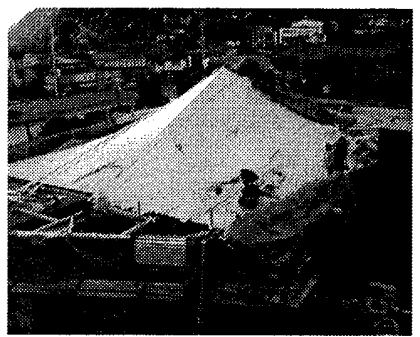

(HPシェル用板 1 痛目敷き込み)

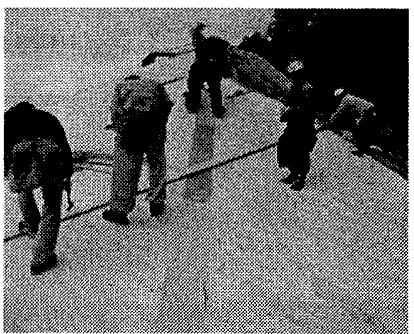

（アラミド瀻維シート㙋付）

写真 3 施工状況
リューボルト) という简単な接 合を実現した。これは若干の施 工蚂差を吸収できるジョイント 材としての効果をも持つものと なっている。

HP シェルは淔線的配圆の板材 の組み合すせにより曲面を構成 することが出来るシステムであ るが、淔線的材であるとはいえ 実際の木板には厚みと幅があっ て、HP シェルの形状を構成する 事によるねじれを、板材である ホワイトウッドに与える事にな る。篗い実の採用はこれを見込 んで出来るだけHP シェル曲面全 体を一体化させることが目的で あったが、仮設工事を含めた HP シェルの組立・設洫工事もこの 観点から検討がなされた。

当初の組立て工事には地組み （シェル先組み）によるノンス テージエ法を考えていたが、完 成した版の用性が大きく、形状 が所定の HP シェルの形状になし まない懸念があった。

そこで現場組立案、つまり建物内部のほぼ全面に仮設支保工を組 み、部材を一-本ずつHPシェルの形状通りに設䈯・取り付けを行うの が無理のない工法と考えられた。ノンステージ工法に比して若干の 手間が增えることとなったが、施工上は笎理なく順調に組み立てる ことができた。

\section{6. 変形の測定}

本越物は 2002 年 1 月に竣エしているが、竣工後もIP シェル本体の ほぼ中央部及び鉄骨張弦梁中央部において、竣工前（2001 年末）上 り継綍して鉛直変位の測定を行っている。2002 年 3 月上旬までは䅡 雪や気候の変化を考甞して溂定の頻度はやや多めに、以降は折を見 て現地を訪れて测定を実施している。

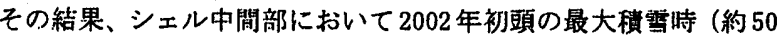
〜 $70 \mathrm{~cm} ）$ における最大たわみが $15 \sim 20 \mathrm{~mm}$ 、鉄骨張弦梁のセンター ストラット下端における最大変形はその後の最高時点の高さからの 変形を見ても $10 \mathrm{~mm}$ 末満であった。测定の精度を繿みても荷重と変形 の関係に不自然な点はさほど栔められず、設計の妥当性が窥えるの

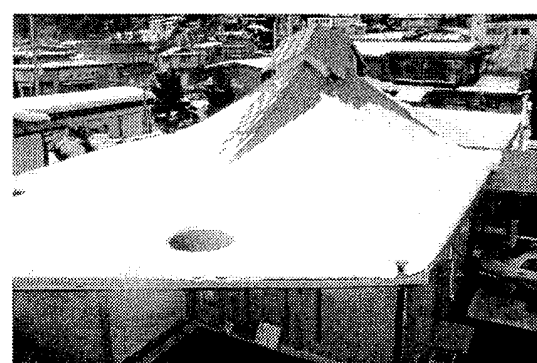

写真 4 積雪時のHPシェル屋根（南側）
ではないかと考えられる（写真 $4 \cdot$ 図 5)。

なおこの測定は垷在も継続して行っており、今後も適当な期間を

置いて計測を実施していくことにしている。
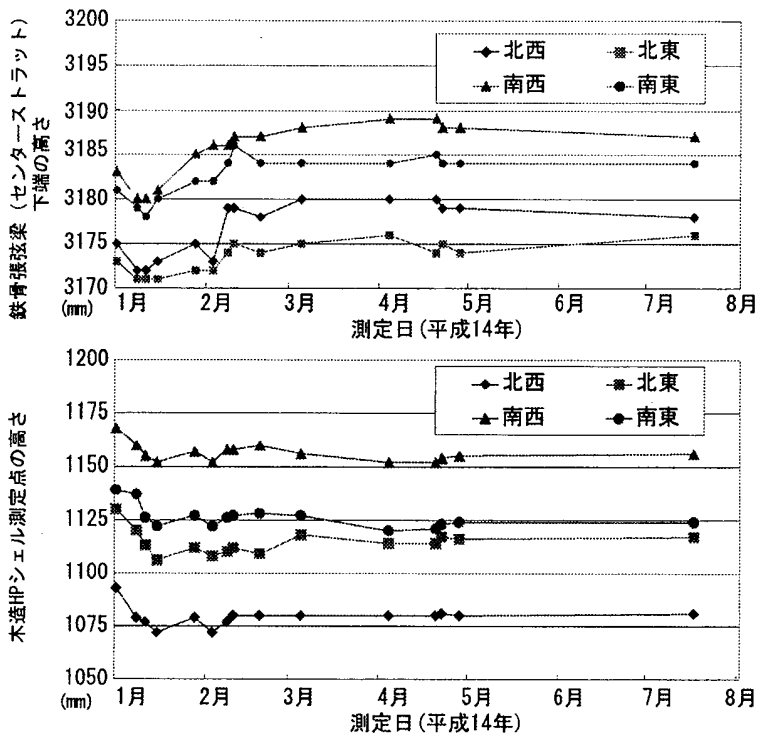

図 5 木造 HP シェル及び鉄骨張弦梁の鉛直高さの変動状況

\section{7. まとめ}

本物件においては 25 mm厚さのホワイトウッドを直交させ、ラグス クリューボルトによって周定した 2 層椿造のHPシェルを粠成、さら に層閒にアラミド瀻維を組み込んでシェルの強度と㴊性を確保して いる。そして鉄骨の張弦梁構造と組み合わせたハイブリッド構造と して、 $16 \mathrm{~m} \times 13.5 \mathrm{~m}$ の大空間を無柱空間として、かつ $1 \mathrm{~m}$ の糟雪に耐 え得る設計を行った設計例の報告であるが、その意義をまとめると 以下の通りと考えている。

（1）市販の製材品木材とラグスクリューボルトを使用した簡易な木 造 HPシェルの実現は沉用性が高い上に、棈成を変えることによりさ らなるスパン延展など、新構法展閒の可能性がある。

（2）木造と鉄骨を組み合わせたハイブリッド䅉造仕近年栐々な形で 発展を遂代てきているが、HPシェルと張弦梁という組み合わせは殆 ど前例が無く、このようなシステムを成立させる事には建築設計及 び瑇造デザインの発展という観点上意義があると考えられる。

（3）アラミド䄉稚は高強度で引張剖性に優れる性質を持ちながら も、建策一般での使用例は極めて少ない。しかし、他の材料との八 イブリッド粺造として用いる事ができるならば、建築及び樓造設計 上におけるデザインの選択肢を公げるという事の意義は極めて大き いと曹える。

湖辞

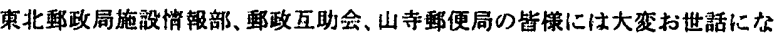

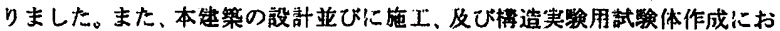

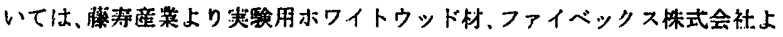

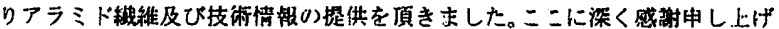
ます。

参考文融

・板垣直行、伊蕂段明、相原俊弘、三ッ井雅人：「HPシェルに用いられだ

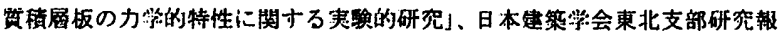
告集・楆造系、第 65 量、PP. 55-58、2002

- Karl-Heinz Gotz, Dieter Hoor, Karl Mohler, Julius Natterer :Timber Design and Construction Sourcebook: A Comprehensive Guide to Methods and Practice 